\title{
Tilfelli mánaðarins:
}

\section{Maður með sýklasóttarlost og rauðkornasundrun}

Inga Jóna Ingimarsdóttir ${ }^{1}$, Lena Rós Ásmundsdóttir², Magnús Gottfreðsson ${ }^{1,3}$

Höfundar eru öll læknar á smitsjúkdómadeild sýklafræðideild Landspítala², læknadeild Háskóla Íslands ${ }^{3}$

Fyrirspurnir: Magnús Gottfreðsson magnusgo@landspitali.is

\section{Saga}

Sjötugur maður með insúlínháða sykursýki kom á bráðamóttöku með háan hita, verk um ofanverðan kvið og uppköst. Einkennin höfðu ágerst undanfarna prjá sólarhringa. Við komu var hann með hita, $40,5^{\circ} \mathrm{C}$, andaði 40 sinnum á mínútu, hjartsláttartíðni var 100 slög á mínútu en blóðprýstingur var eðlilegur og súrefnismettun án súrefnis sömuleiðis. Hann var vakandi, meðvitund óskert, en litarhaft heiðgult. Eymsli fundust við preifingu á kvið.

Hvít blóðkorn voru 23,0 x10/L (4,0-10,5), hemóglóbín 105 g/L (134-171), hematokrít 0,34 L/L, kreatínín 77 umól/L (60-100), blóðflögur $355 \times 10^{9} / \mathrm{L}$ (150-400), glúkósi 23,7 mmól/L (3,9-5,8), laktat 8,7 mmól/L (0,5-1,6) og CRP $152 \mathrm{mg} / \mathrm{L}(<10)$. Truflun var á lifrarprófum (ALP 216 IU/L [35-105], GGT 310 IU/L [<115], ALAT 140 IU/L [<70] og heildarbilirúbín 127 нmól/L [5-25]).

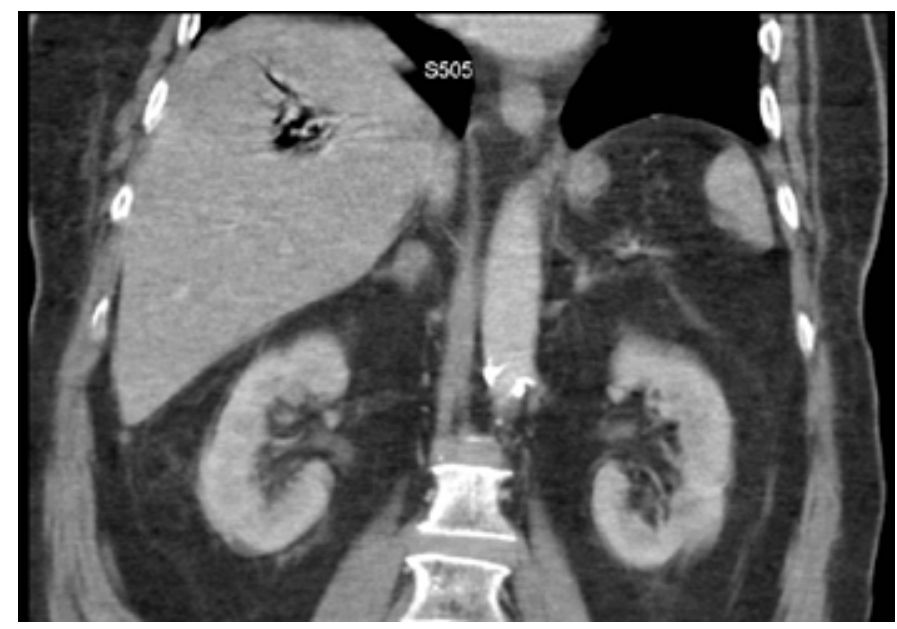

Mynd 1. TS-mynd af kvið við komu á bráðamóttöku sýnir sýkingargrunsamlega breytingu í lifur ásamt loftmyndun.
Settur var pvagleggur og kom pá lítið af dökkrauðu pvagi. Strimilpróf sýndi 4+ af sykri og 3+ af ketonum. TS-mynd af kvið sýndi loftmyndun í lifur (mynd 1). Hafin var meðferð með insúlíndreypi og vökva, teknar ræktanir og sjúklingur settur á Ampicillin, Cefuroxím og Metronidazól í æð. Útskilnaður var einungis $15 \mathrm{~mL}$ fyrstu fjórar klukkustundirnar og var hann pví tengdur við nýrnaskilunarvél. Endurtekin blóðprufa sýndi hvít blóðkorn 21,3 ×10/L, hemóglóbín 70 g/L, hematókrít 0,19 og blóðflögur 607 x10\% / Hann fékk samtals fjórar einingar af rauðkornapykkni og sjö einingar af blóðflögum. Hann féll í blóðprýstingi, var barkapræddur og lagður í öndunarvél. Blóðsýni var afar óeðlilegt séð með berum augum, sermi svartleitt (mynd 2). Daginn eftir greindust gram-jákvæðar staflaga bakteríur í blóðræktun.

Hver er sjúkdómsgreiningin?

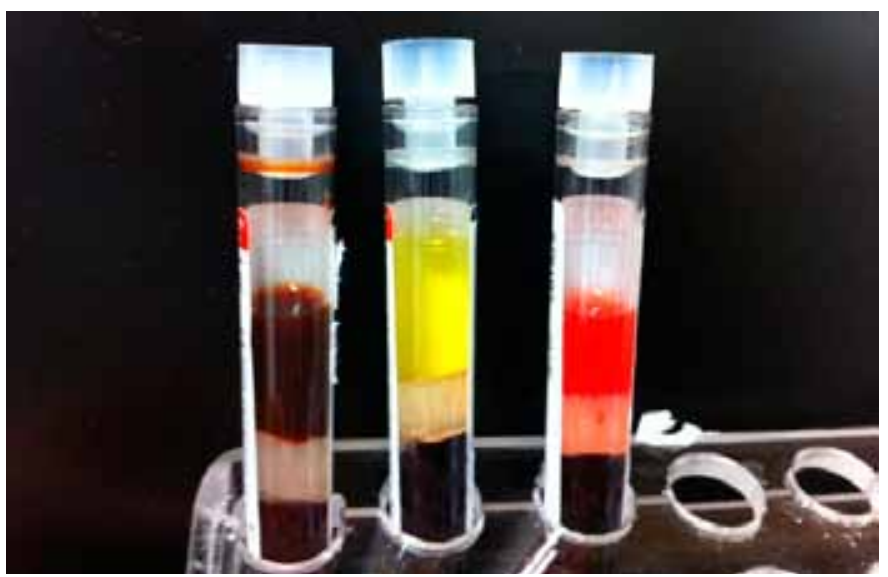

Mynd 2. Blóðrrufa sjúklings (lengst til vinstri) tekin á gjörgæsludeild á öơrum degi. Hún sýnir svartleitt sermi vegna gríðarmikillar rauð̌kornasundrunar. Í miððjunni sést eðlileg blóðprufa með gulu sermi efst. Lengst til hægri en blóðprufa með vægri rauðkornasundrun. 


\section{Svar við tilfelli mánaðarins}

\section{Svar og umræða}

Sjúklingur var með sýklasóttarlost, blóðstorkusótt (disseminated intravascular coagulation) og bráđa nýrnabilun ásamt gríðarlegri sundrun á rauðum blóðkornum (hemolysis). Úr blóðræktun ræktaðist Clostridium perfringens og Escherichia coli, en pvagræktun var neikvæð. Hann fékk blóðprýstingshækkandi lyf, vökva, blóðgjöf og blóðflögur. Sýklalyfjameðferð var breytt í Piperacillin/Tazobactam í æð. Prátt fyrir öfluga stuðningsmeðferð fór ástand hans versnandi, með fjöllíffærabilun, hjartastoppi og andláti að morgni priðja legudags. Við krufningu sást kýli í lifur með drepsvæði í kring og við smásjárskoðun á lifrarvef sáust gram-jákvæðar staflaga bakteríur. Ekki greindust merki um illkynja vöxt eða rof á meltingarvegi.

Clostridium perfringens er loftfirrð, sporamyndandi gram-jákvæð staflaga baktería af ætt Clostridia. Bakterían er til staðar í náttúrunni, bæði í jarðvegi og getur verið hluti af eðlilegri bakteríuflóru í meltingarvegi hraustra manna og dýra. Ekki er óalgengt að C. perfringens valdi matareitrun. ${ }^{1}$ Bakterían getur einnig valdið drepi með loftmyndun út frá sárasýkingum, eftir fæðingu, fóstureyðingu eða annað sem veldur rofi á húð eða slímhúðum, til dæmis í meltingarvegi eða gallvegum. ${ }^{2}$ Sýklasótt með C. perfringens verður oftast hjá ónæmisbældum sjúklingum, eða peim sem eru með sykursýki og/eða illkynja sjúkdóma, ${ }^{2}$ en hefur einnig verið lýst hjá hraustum einstaklingum. ${ }^{3}$

Mikil sundrun á rauðum blóðkornum (massive hemolysis) er sjaldgæfur fylgikvilli C. perfringens blóðsýkingar og tengist afar hárri dánartíðni, 70-100\%., ${ }^{4,5}$ Ástæða pessarar sundrunar er myndun bakteríunnar á $\alpha$-toxíni, sem er eiturefni sem hefur meðal annars fosfólípasa $C$ virkni. ${ }^{6} \alpha$-toxínið ræðst á frumuhimnu rauðra blóðkorna og sundrar peim, pannig að frítt hemóglóbín lekur út í sermi og getur pví orðið mikið misræmi á mæliniðurstöðum fyrir hemóglóbín og hematókrít. Aðeins fáeinar aðrar sýkingar geta valdið eyðingu eða sundrun á rauðum blóðkornum, par á meðal malaría (sérstaklega Plasmodium falciparum), bartonellosis, babesiosis og sýkingar með shiga-toxínmyndandi bakteríum, par sem E. coli O157:H7 er pekktasta dæmið (hemolytic-uremic syndrome, HUS, eða rauðkornasundrunar- og nýrnabilunarheilkenni). Ekki er hægt að útiloka pann fræðilega möguleika að E. coli hafi átt einhvern pátt í sjúkdómsmyndinni, enda pótt pað hljóti að teljast fremur langsótt. Til viðbótar við $\alpha$-toxín framleiðir $C$. perfringens nokkur önnur eiturefni, par á meðal perfringolysin $\mathrm{O}$ sem hefur verið bendlað við blóðstorkusótt í sjúklingum með sýklasótt.7 $C$. perfringens blóðsýking getur leitt til nýrnabilunar sem getur verið afleiðing lágprýstings, hemóglóbínmigu og myoglóbínmigu.
Sjúkdómar í lifur og gallvegum eru algengasta uppspretta $C$. perfringens blóðsýkinga eins og í pessu tilfelli. ${ }^{8}$ Meðaldánartíðni sjúklinga með C. perfringens sýkingu í blóði er $27 \%$, en sýklasóttarlost, blóðstorkusótt og greinanleg loftmyndun tengist verri horfum $^{8}$ eins og raunin varð hér. C. perfringens er yfirleitt vel næm fyrir mörgum sýklalyfjum, par á meðal penicillín-samböndum og er oft mælt með penicillíni G við staðfestum sýkingum. Virkni kefalosporína hefur ekki verið mikið rannsökuð in vivo, enda pótt sýnt hafi verið fram á virkni peirra in vitro. Upphafsmeðferð með Cefuroxími í æð er algeng hjá sjúklingum með kviðarholssýkingar á skurðdeildum, en telst ekki vera kjörmeðferð C. perfringens blóðsýkinga. Sýklalyfjameðferð var pví breytt fljótlega eftir komu. Á hinn bóginn rennir petta tilfelli og önnur ápekk stoðum undir pá kenningu að hinar slæmu horfur sjúklinga tengist að verulegu leyti myndun bakteríunnar á eiturefnum sem hugsanlega halda áfram að skaða sjúkling pótt bakteríurnar séu drepnar. Ekki er mælt með аð gefa sýklalyf pegar um matareitrun af völdum $C$. perfringens er аð ræða.

\section{Heimildir}

1. Sparks SG, Carman RJ, Sarker MR, McClane BA. Genotyping of enterotoxigenic clostridium perfringens fecal isolates associated with antibiotic-associated diarrhea and food poisoning in north America. J Clin Microbiology 2001; 39: 883-8.

2. Rechner PM, Agger WA, Mruz K, Cogbill TH. Clinical features of clostridial bacteremia: a review from a rural area. Clin Infect Dis 2001; 33: 349-53.

3. Leal J, Gregson DB, Ross T, Church DL, Laupland KB. Epidemiology of Clostridium species bacteremia in Calgary, Canada, 2000-2006. J Infect 2008; 57: 198-203.

4. Rogstad B, Ritland S, Lunde S, Hagen AG. Clostridium perfringens septicemia with massive hemolysis. Infection 1993; 21: 54-6.

5. Kreidl KO, Green GR, Wren SM. Intravascular hemolysis from a Clostridium perfringens liver abscess. J Am Coll Surg 2002; 194: 387.

6. Hubl W, Mostbeck B, Hartleb H, Pointner H, Kofler K, Bayer PM. Investigation of the pathogenesis of massive hemolysis in a case of Clostridium perfringens septicemia. Ann Hematol 1993; 67: 145-7.

7. Bryant AE. Biology and pathogenesis of thrombosis and procoagulant activity in invasive infections caused by group A streptococci and Clostridium perfringens. Clin Microbiol Rev 2003; 16: 451-62.

8. Fujita H, Nishimura S, Kurosawa S, Akiya I, Nakamura-Uchiyama F, Ohnishi K. Clinical and epidemiological features of Clostridium perfringens bacteremia: a review of 18 cases over 8 year-period in a tertiary care center in metropolitan Tokyo area in Japan. Intern Med 2010; 49: 2433-7.

Case of the month: Patient with septic shock and massive intravascular haemolysis

Key words: Septic shock, massive haemolysis, Clostridium perfringens.

Tilfellið barst 5. mars 2012, sampykkt til birtingar: 20. apríl 2012. 